\title{
Bidrag til en karakteristik af identitetskonstruktion på nettet - fra virtuel til medialiseret identitet
}

\author{
Tina Thode Hougard \\ Aarhus Universitet
}

Efter en kort introduktion til den tidligere forskning i identitet og computermedieret kommunikation undersøges forskellige eksempler på konstruktion af netidentitet $\mathrm{i}$ henholdsvis dansk webchat og på Facebook. Hvor der i chat var meget fokus på leg med køn og identitet, er der på de aktuelle sociale medier i højere grad tale om selvrapportering og -iscenesættelse og på at være anerkendelsesværdig. Artiklen slutter af med at foreslå begrebet "medialiseret identitet" for at understrege mediernes centrale rolle i den enkeltes identitetsarbejde.

\section{Indledende bemærkninger om netidentitet}

Ifølge socialkonstruktionismen er vi som interagerende mennesker relationelt orienteret (Gergen \& Gergen 2005). Det betyder dels at vi forhandler betydningen af vores ytringer i fællesskab, dels at den respons vi får på det vi siger og gør, har betydning for vores selvopfattelse og handlinger. Vores identitet er social, og udviklingen af den er således afhængig af de muligheder som de andre, dvs. samfundet, giver os for at forhandle og forstå os selv, vores personlighed og særlige træk (Togeby 2014). Identitet er rent psykologisk at forstå som "et menneskes bevidsthed om egen personlighed og individuelle særpræg" (DDO).

Den verserende diskussion om hvorvidt den enkeltes identitet udelukkende kan forklares som et resultat af sproget, dvs. at sproget skaber mennesket, eller om menneskets identitet er grundlagt med generne og dermed eksisterer som førsproglig præmis for den enkeltes selvforståelse, vil denne artikel kun bidrage til indirekte. Jeg vil nemlig prøve at give et bud på hvilken betydning interaktion via sociale medier har for identiteten. At det at udveksle tanker på skrift kan fungere som et redskab til forståelse af sig selv, er ikke noget nyt fænomen. Det vidner mange berømte brevvekslinger om, men er det også identiteten 
og selvforståelsen der forhandles når der chattes eller skrives statusopdateringer på Facebook? Er netidentiteten en del af den enkeltes samlede identitet eller snarere en leg med denne - et ikke determinerende supplement? Hvilken betydning har det interaktive element, dvs. det at man får eller har mulighed for at få respons, på identiteten?

I denne artikel vil jeg undersøge hvad man prøver at opnå i forhold til identitet når man skriver på de sociale medier. Med udgangspunkt i analyser af konkrete interaktioner i dansk webchat og på Facebook vil jeg give et bud på en forståelse af det identitetsarbejde der foregår i skriftlig interaktion i sociale medier. Jeg undersøger konstruktionen og forhandlingen af netidentitet. Inden for den forståelsesramme at det både i chatten og på Facebook handler meget om at generere respons, vil jeg diskutere hvilken type forhandling af identitetsarbejdet der foregår i disse interaktioner. Min påstand er at identitetsarbejdet både i chat og på Facebook er afhængig af feedback, og at mængden og typen af feedback får betydning for dette identitetsarbejde.

Artiklen er først og fremmest en analyse af identitetskonstruktion, dvs. opbygning og demonstration af identitet, i dansk webchat, men eftersom chat i dag ikke har samme popularitet som i halvfemserne og nullerne, har jeg vurderet det relevant $i$ et fremadrettet perspektiv at sammenligne med hvad der i dag sker af lignende handlinger på Facebook. Kan nogle af de træk der umiddelbart ser ud til at kendetegne Facebook, drages tilbage til webchatten? Minder identitetskonstruktionerne om hinanden? Er det mere rimeligt at arbejde med begrebet "medialiseret identitet" end "virtuel identitet" i forbindelse med de sociale medier?

Identitetskonstruktion undersøges i en afgrænset dansk kontekst. De anvendte data vedrørende dansk webchat stammer fra min ph.d.afhandling fra 2004, hvor jeg undersøgte interaktionsmønstre, dominerende sproglige kendetegn og responsfremkaldelse. Disse data blev indsamlet i år 2000 i det chatforum der dengang eksisterede under navnet Opasiachat. De anvendte data vedrørende Facebook er indsamlet blandt mine egne facebookvenner i efteråret 2012 og foråret 2013. Eftersom min undersøgelse af dansk webchat talte godt 8000 indlæg, og mit facebookkorpus er meget mindre og mere sporadisk ${ }^{1}$, bliver den konkrete sammenligning ikke det bærende element i min artikel, men kommer i højere grad til at pege på mulige ligheder og forskelle og fremtidige undersøgelsesmuligheder.. 
Bidrag til en karakteristik af identitetskonstruktion på nettet ...

\section{Tidligere forskning i identitet i computermedierede sammen- hænge}

\subsection{Identitetsskift, køn og anonymitet}

Et af de emner der blev tematiseret meget tidligt i udforskningen af computermedieret kommunikation (CMC), var spørgsmålet om cybersocialitetens indflydelse på den enkeltes identitet. Forskningen har i høj grad beskæftiget sig med den virtuelle identitet og herunder med chattens og lignende virtuelles verdeners enorme mulighedsfelt som "identity workshop" (Turkle 1995, Bruckman 1993). Men også spørgsmålet om hvorvidt identitetsdannelsen generelt blev påvirket af leg i chatrum har været diskuteret (Sørensen 2001).

Uden den fysiske krop til at markere køn, race og alder var deltagerne ifølge den tidlige forskning frie og eksisterede kun som virtuelle udtryk hvis fysiske herkomst var mindre væsentlig; "the nature of identity vanished under the new electronic dispensation" (Stone 1992:83). Den forsvundne krop tillod eksperimenter med identitet og seksualitet (Turkle 1995). "[T] he typed text provided the mask" (Danet 1998:129) og fik mennesker der før ikke havde været interesseret $i$ at skifte identitet, til at eksperimentere med identiteten og kønsidentiteten i skriftlige netmøder:

Engagement with computational technology facilitates a series of "second chances" for adults to work and rework unresolved personal issues and more generally, to think through questions about the nature of self, including questions about definitions of life, intentionality, and intelligence (Turkle 1995:145).

Ifølge Kolko er den forsvundne krop dog en myte som har bevirket en inkonsistens mellem det virtuelle og det fysiske selv (Kolko 1999). Flere forskere påpeger at den fysiske krop uvilkårligt er inddraget i online kommunikation (Herring 1999, Kolko 1999), og at det virtuelle til trods for sin tiltrækkende og manipulerende modus ikke kan udviske det fysiske (McRae 1997, Turkle 1995). Orienteringen mod den kønnede krop og stereotype kønsopfattelser er reproduceret i CMC (Danet 1998) og fremstår om muligt endnu mere stereotypt og undertrykkende i grafiske virtuelle verdner (Kolko 1999:179). Den teknologiske kapacitet er til en vis grad udslagsgivende for det kommunikerede, men " $[\mathrm{t}]$ hese avatars are what I would call visual aphorisms, and like verbal aphorisms, they reveal what a culture takes to be "self-evident truths" (Kolko 1999:183). 


\section{Tina Thode Hougaard}

Anonymiteten med visuel og auditiv distance blev set som en afgørende faktor for CMC's påvirkning af den enkeltes identitetsarbejde idet deltagerne ikke var indskrænket af den fysiske identitet, men kunne chatte med "ideal and multiple selves" (Turkle 1999:5). Ved anonymitet i chat forstås det forhold at den rigtige identitet maskeres af et dæknavn, nickname. I forhold til andre relativt anonyme kommunikationsformer, som fx det anonyme læserbrev, er der i chat ingen regulerende instans der skal kende aktørens rigtige identitet. Chat fremstår dermed umiddelbart som et frit og utvungent forum hvor mennesker kan mødes uden sociokulturelle og biologiske funderede fordomme. Flygtigheden $\mathrm{i}$ interaktionsformen opfordrede ikke umiddelbart til et nøjere studie af deltagernes identitet og troværdighed.

Selv om anonymitet som chatinteraktionens grundvilkår gav chatdeltagerne rig mulighed for at iscenesætte deres virtuelle identitet fuldstændig uafhængig af deres offline-identitet, tyder meget på at chatterne i mine data snarere opfatter deres dæknavn som et pseudonym og deres chatidentitet som meget beslægtet med deres off-line-identitet - i reglen som et koncentrat af de positive og interessante sider (Bays 1998). Dette kan hænge sammen med at webchat i hvert fald i Danmark mere blev rammesat som et mødested end som en legeplads, men det kan også lægge op til en problematisering af den tidlige næsten euforiske begejstring over det man så som det chattende menneskes åbenlyse behov for og tendens til at frisætte og nytænke identiteten og forståelsen af identiteten som given og uforanderlig. Med den aktuelle udvikling af de sociale medier, hvor en skelnen mellem offline- og onlineidentitet ikke mere synes at bidrage til afklaring af deltagernes identitetskonstruktion, er der meget der tyder på at attraktionen ikke så meget ligger i legen med forskellige identiteter som i det at høste anerkendelse for den identitet eller i det mindste den fremstilling af identiteten som man kan opvise.

I løbet af nullerne afløstes den anonyme interaktion stort set af netværksinteraktion mellem venner og bekendte (Linaa 2010) samtidig med at den visuelles identifikation via webcam og privatfotos næsten eliminerede anonymiteten som mulighed. Selv om der stadig er mulighed for at operere under dæknavn, som fx Bitterfissen ${ }^{2}$, går tendensen $\mathrm{i}$ retning af mere autenticitet og oprigtighed. Interaktionen på de sociale medier har ofte karakter af hverdagsblogging eller miniblogging forstået som formidling af den enkeltes egenregistrering af eller beretninger om hændelser og handlinger. Dette sker i stigende grad med integrering af billeder, ofte via mobiltelefonens kamerafunktion. På trods af denne 
selvrapportering, der nogle gange udmønter sig i decideret selvafsløring og blottelse, kan det dog diskuteres om dette har afgørende betydning for den enkeltes identitet og selvforståelse eller det stadig er en iscenesættelse og et rollespil (Goffman 1992), der nu blot foregår i fuld net-offentlighed (Villesen 2005).

Ligegyldig om interaktionen foregår $\mathrm{i}$ komfortabel anonymitet eller mere åbenbart, er der fokus på det at få respons som en art bekræftelse på at nogen har læst ens indlæg og har ønsket at relatere til det og personen bag det. Meget af interaktionen i de sociale medier er relationskommunikation (Watzlawick 1968) idet deltagerne bruger sproget både eksplicit og implicit til at markere og forhandle deres indbyrdes relation og opfattelse af sig selv og hinanden og dermed deres sociale identitet. I forhold til spørgsmålet om identitet vil den afgørende forskel på de chat og de sociale medier umiddelbart bestå i hvilke konsekvenser identitetskonstruktionen har, og her er det i forste omgang interessant at notere sig at mens chat forblev en hobby for de få, er udbredelsen af interaktion via de sociale medier langt mere udbredt. ${ }^{3}$ Interessen i at eksistere som en søgbar og evt. handlende identitet i de sociale medier er stor, og selv om nogle af disse deltagere ikke udøver regelmæssig aktivitet $\mathrm{i}$ form af ugentlige statusopdateringer eller kommentarer, er der stadig rig mulighed for identitets- og relationsarbejde, fx når fødselsdagen markeres af fødselarens kontakter:

Eks.1

Kære J. Ja, når man bor i kolonihaven er man ikke konstant online på de hersens sociale medier. Og det er jo skønt. Men man glipper jo vigtige personers fødselsdage. Modtag et forsinket tillykke herfra...kh $\mathrm{R}^{4}$

I denne fødselsdagshilsen anerkender afsenderen $\mathrm{J}$ som en vigtig person, og selv om ikke alle facebookbrugere har en helt åben profil, dvs. hvor ikke relaterede kan læse alle opslag, vil meget af interaktionen på den enkeltes facebookvæg være tilgængelig for alle dennes venner.

\subsection{Identitet, refleksivitet og sociale medier}

Med de sociale mediers udbredelse oplever den enkelte ifølge Tække (2010) en større transparens i forhold til sin gøren og laden. Når man skriver statusopdateringer på fx Facebook, er det refleksive fremskrivninger af den enkeltes identitet - en selvfremstilling - fordi vi på nettet præsenterer og fremstiller os selv med de midler og medier vi har til rådighed, og $\mathrm{i}$ den optik eller forståelsesramme som disse medier giver os adgang til. Denne selvfremstilling er ifølge Scott Sørensen ek- 
sempler på "en hverdagslivets diskurs" (Scott Sørensen 2012:146), som dog af mange forsøges givet "en almen form, der kan have interesse for alle deltagende" (ibid.) som en slags "des-interesseret socialitet" (ibid.) hvor de andre indtænkes som publikum der skal underholdes eller udfordres med henblik på at maksimere hinandens fornøjelse. Mange af brugerne er orienteret mod at kommunikere med samtalens spontanitet og informalitet og mod at signalere nærvær og tilgængelighed, samtidig med at der også er fokus på at vedligeholde en "konstant, perifer opmærksomhed" (Lomborg 2013:102) på ens relationer.

En af Tækkes pointer er at der med de sociale medier forstået som netværk og ikke fællesskaber opstår en form for samvær uden fælles meningsgrænse. Meningsgrænse definerer han i forlængelse af Luhmann (2000) som det at der er dannet normer for hvad man kan tale om (sagsdimensionen), og hvordan (socialdimensionen) (Tække 2010:11). Men den forhandling af regler og normer, der bl.a. kendetegner et fællesskab, er ikke eller kun i ringe grad til stede i de sociale medier, så den enkeltes mulighed for at forstå sig selv i kraft af og i forhold til de andre foregår kun i et 1:1-forhold uden den fælles akkumulerede korrigerende kraft som et fællesskabs normer kan bidrage med. Den enkelte ved derfor ikke hvad der generelt set 'tæller' i denne sociale sammenhæng, og heller ikke hvad man kan regne med fra de øvrige deltagere fordi disse er "troløse" (Gurak og Antonijevic 2009, Warnick 2007) og ikke føler sig forpligtede til at bidrage til hinandens identitetsarbejde. I netværkssocialiteten er deltagelse mulig, men ikke nødvendig (Scott Sørensen 2012:133). Fremmedreferencen (de andres kommentarer etc.) er derfor ikke stabil og gør det ifølge Tække sværere for den enkelte at forholde sig til sig selv og reflektere over egen selvfremstilling. Man mangler en klar referenceramme og reel spejlingsmulighed (Tække 2010:13).

Tække beskriver iagttagelsessituationen som en opsvulmning af Meyrowitz's "middle region" (Meyrowitz 1986:43) fordi backstageviden konstant blottes, og fordi vores evne til publikumsbevidsthed og modtagerorientering presses til det yderste. Man kan derfor diskutere om det overhovedet giver mening at diskutere identitet i forhold til de sociale medier, og om man ikke hellere skulle se det som en udgave af de goffmanske roller i overfladinteraktionen hvor den enkeltes evne til at fremføre sin rolle og følge spillets regler er afgørende for dennes succes i livet (Goffman 1992). Interaktionen på nettet sætter spot på det skisma vi befinder os i som kommunikerende individer, for hvis sproget er vores eneste middel til at fremskrive identiteten, bliver denne 
fuldstændig afhængig af sproget og vores sproglige muligheder og begrænsninger. På nettet eksisterer den enkelte kun i kraft af dennes samledes kommunikation, og selv om dette også inkluderer billeder og ens relationers beskrivelser og andre sproglige handlinger, vil de fleste nok mene at deres personlighed er mere sammensat end den der formidles på nettet. I stedet for at være et udtryk for vores identitet er interaktionen i de sociale medier derfor snarere et udtryk for vores sproglige evne eller mangel på samme til at udtrykke vores identitet. Interaktionen er altså snarere en funktion af vores identitet idet vores interaktion netop er det der kommer ud af vores identitet når denne sættes $i$ denne specifikke situation, hvor eksistens afhænger af kommunikation.

I relation til netsocialiteten er det centralt at skriftsproget er vores adgang til at fortælle om os selv og til at formidle vores eget selvbillede eller det vi mener er vores identitet. Det nye i denne diskussion som netdimensionen kan bidrage med, er bl.a. det at den refleksive praksis potenseres med den potenserede skriftlighed. Bevidstheden om at vi konstant befinder os $\mathrm{i}$ en identitetsformidlende situation, gør at vores refleksion over identitetens sammensathed og over vores evne til at give udtryk herfor bliver mere presserende. I modsætning til chattens samtalelignende interaktionsform med spontane ytringer og næsten-synkrone interaktionstempo lægger de sociale mediers sænkede interaktionshastighed og bevidsthed om dataveillance (at alle afgivne bidrag lagres og kan genfindes) op til en højere grad af refleksion.

Desuden betyder det faktum at publikummet er multipelt (Donath \& boyd 2004) og ofte sammensat af både venner, familie, kolleger, tidligere kærester og måske også chefer og elever at man på Facebook har mange forskellige samtidige relationer og roller og derfor i højere grad end $\mathrm{i}$ chatten må diskutere med sig selv om hvilket billede man ønsker at vise frem til alle på én gang (Tække 2010). Den situationstilpasning og attituderelativisme der normalt gør sig gældende i interaktionssituationer hvor konteksten og publikum bestemmer hvilken side af ens identitet man stiller til skue, er umuliggjort på Facebook, med mindre man opererer med flere profiler med forskellige grader af offentlighed eller gør brug af muligheden for filtre. Men de flestes profiler henvender sig til alle på én gang (Scott Sørensen 2012), og deltagerne har dermed ikke muligheden for at isolere bestemte personlighedstræk og tilpasse kommunikationen til situationen, men oplever i stedet "social divergens" (ibid.). Med goffmanske begreber kan man sige at alle roller skal spilles i samme situation. 


\section{Tina Thode Hougaard}

Ifølge Tække presses den enkelte altså til en yderst refleksivt distanceret position hvor interaktionshensynet vinder over sagsdimensionen (Tække 2010:16), og hvor man lægger restriktioner på udtrykket og indholdet så det passer til alle relationer. Man kan dermed frygte at mangfoldigheden i sagsdimensionen svinder ind fordi alle indlæg skal kunne læses af alle. Men i denne sammenhæng er det efter min mening mere interessant at diskutere hvilken betydning det har for den enkelte at akkommodere og tilpasse sin identitet og identitetsfremstilling konstant. Bliver selvfremstillingen overfladisk og hysterisk intim (Miller 2008), bliver den socialt koreograferet eller stiliseret som "a publicized mode of appearance" (Butler 2005), eller er det kravene om kontinuitet, konsistens og variation (Scott Sørensen 2012:141) der bliver afgørende for hvordan vi fremstiller os selv på Facebook?

I socialkonstruktivistisk optik er vi alle medforfattere på hinandens selvfremstilling og dermed også aktører i hinandens identitetsarbejde. Hvis ens identitet er en social konstruktion, er spørgsmålet om den forhandling og det samarbejde der foregår i de forskellige sociale medier, er forpligtende nok til at det faktisk får konsekvenser for vores identitetsarbejde? En afgørende forskel på identitetskonstruktionerne i chatuniverserne og de senere forskellige netværkstjenester som fx Facebook er netop at samværsformen har ændret sig fra interessefællesskaber til netværk og fra identitetsleg og anonymitet til selvrapportering og hverdagsinteraktion mellem venner. Det vil kræve en større undersøgelse at få denne ændrings konsekvenser for den enkeltes identitetsdannelse belyst ordentligt, men jeg vil her i artiklen give nogle bud på hvordan det kunne undersøges, og hvilke pejlinger mit materiale giver.

\section{Identitet i chat}

De følgende analyser undersøger webchat indsamlet i foråret og efteråret $2000 \mathrm{i}$ det danske chatforum "Opasia-chat" der var hostet af Tele Danmark. Min undersøgelse inkluderede to af de mange forskellige chatrum, nemlig Andre Unge (med deltagere i alderen 12-23) og Andre Seniorer (med deltagere i alderen 30-55 på nær 2-3 deltagere omkring 20 år) (Hougaard 2004:79).

\subsection{Daknavne og selvfremstilling}

Chat blev pga. muligheden for anonymitet i begyndelsen beskyldt for at føre til eskapisme og mangel på evne til at skelne mellem den fysiske og den virtuelle virkelighed, men mit materiale viste dels at mange 
Bidrag til en karakteristik af identitetskonstruktion på nettet ...

chattere ønskede en fast virtuel identitet idet de altid chattede under samme dæknavn, dels at mange chattere kendte til hinandens privatliv; nogle udvekslede endda personlige data og mødtes uden for det virtuelle rum (Hougaard 2004:11).

Dæknavnet blev opfattet som et kaldenavn eller pseudonym og fungerede ofte som en form for tillempet face på chatten (Bays 1998) idet man med sit dæknavn kunne vælge hvilke dele af sit selvbillede man ønskede at formidle, fx "chatforskeren", "TeChNoTøzen" og "Søren29", hvor man som modtager informeredes om henholdsvis erhverv eller hensigt, interesse og alder med tilhørende forventninger om at personen $i$ hvert fald i en vis udstrækning havde en adfærd der stemte overens med dette face. Særligt talangivelsen, der oftest blev forstået som refererende til chatterens alder, regnedes for en central og forpligtende angivelse der fordrede overensstemmelse med chatterens handlinger og adfærd. Men vigtigere endnu var nok den tilknyttede forventning om overensstemmelse mellem tallet og den virkelige alder så Jonas 17 ikke pludselig viste sig at være Jonas på 57 år. Forskellige dæknavne, som fx Pornstar 14 og Maria!!, fremkaldte divergerende associationer og indbød til forskellige former for interaktion.

Selv om brugen af dæknavne som udgangspunkt tjente det formål at fungere som middel til identifikation og adressering, var markeringen af virtuel identitet og position også central. Allerede med sit dæknavn markerede siMz*KiCk azZ* sig eksempelvis som en der "sparker røv", hvad der kun understregedes af hendes ekspressive og grænseafprøvende interaktionsstil. siMz*KiCk azZ* skrev mange indlæg hurtigt efter hinanden og med mange forskellige adressater. Hun udformede alle sine indlæg med et skift mellem store og små bogstaver og med alternativ ortografi, som fx lydstavning og afsnubning:

Eks.2

*gLæDer zarJ tE hUn zKaL tE fÆzzD hOz mP mÆ JulLæ unD cuLty* $\left.* \mathrm{Ti} \mathrm{Hi}^{*}=\right)$

(oversættelse: glæder sig til hun skal til fest hos MP med Julle og Culty)

Med sin intense interaktionsstil konstruerede hun en position der var engageret og allestedsnærværende. Hendes skrivestil vidnede om lyst til at afprøve grænserne for den ortografiske gengivelse samtidig med at skrivestilen sammen med det bestemte farvevalg var hendes kendemærke. 
siMz*KiCk azZ* var en hyppig og dermed kendt deltager i chatrummet, men også chattere der kun optræder kortvarigt i mit materiale, viste hvordan et velvalgt dæknavn kan befordre interaktion. Da McBitter loggede på med følgende konfronterende åbning:

Eks. 3

I think this chat is a kind of bla bla bla.

affødte det mange responser:

Eks. 4

Mc, hvor stammer du fra??*GG*

McBitter: er du eller skænker du *bitter*

Hvad kan man så bruge bitterhed til ???

McBitter beskrev derefter sin bitterhed som resultat af 19 år i venteposition på at "få en pige", og det medførte en del kommentarer af både opmuntrende og kritiserende art fordi McBitter både via sit dæknavn og sine indlæg fremstod som et bittert og vredt menneske. En enkelte prøvede dog at læse andre elementer ind i hans identitet:

Eks. 5.

*Med et nick som McBitter..er man trods alt ikke helt uden selvironi.. ${ }^{*} \mathrm{GG}^{*}$.

Men ingen betvivlede hverken McBitters selvfremstilling eller identitet. De tog umiddelbart hans beskrivelse for pålydende, forholdt sig til ham som bitter og tog hans emne seriøst. Responserne var af helt divergerende karakter fra det coachende til det kritisk vurderende og afstandtagende:

Eks. 6

Bitter...Men det kräver jo, at du er lydhör overfor hende*s* Bitter $>>$ Vågn da for fanden op og nyd livet.....der er ingen returret..........

McBitter......forstår bedre og bedre at du er alene. 
McBitter optrådte kun denne ene gang i mine data, så det er ikke umiddelbart til at afgøre hvilken intention der lå bag hans besøg og hans identitetsfremskrivning som vred og bitter på livet, men selv om han ikke tilhørte inderkredsen af chattere, opnåede han overraskende god respons idet ingen af hans indlæg forblev ukommenterede, og enkelte endda fik flere responser. Det er måske grunden til at McBitter endte med at supplere sin identitetsfremstilling med en mere høflig og andægtig tone i sin farvelhilsen:

Eks. 7.

Gooodbyyyyeeeeee!!! God chat til alle uanset hvad *sv* // Opti > Jeg ved det ikke, men måske har du ret *ss* lydhør er jeg altid for alle. Takker allernådigst! Byeee!

Med Goffmans termer kan man sige at McBitter til slut forsøgte at anlægge en linje der i højere grad betonede at nok var han bitter på livet, men han var stadig er imødekommende menneske, dvs. en det var værd at bruge tid på.

\subsection{Forhandling af køn og identitet $i$ chat}

Den enkelte chatter kunne dels via sit dæknavn, dels via sin interaktionsstil og valg af samtaleemner tegne et billede af sin virtuelle identitet. Identitetsfremskrivning foregik ganske givet mere eller mindre bevidst og sikkert også gradvist, men det kan mit materiale desværre ikke belyse. Det kan i stedet give nogle eksempler på hvordan forskellige deltagere forhandlede opfattelsen af hinandens virtuelle identitet.

Når identitetsproduktionen og identitetsforståelsen, der handler om at "samle og utvikle informasjon om seg selv" (Stuedahl 1998:27), ikke længere umiddelbart knyttes til den fysiske krop eller repræsentationer af den, må betydning som sagt skabes og akkumuleres i sproget. En stor del af identitetskonstruktionen handlede om køn, og der hvor formidlingen af kønnet og selvet skete mest eksplicit, var i dæknavnene, i eksplicit bestemmelse af eget eller andres køn, i kønssprog og i kønsstereotyp adfærd, fx i aggressive eller emotionelle handlinger.

Kønnet tematiseredes ofte $\mathrm{i}$ chat. Chatterne positionerede sig i vid udstrækning som aktører hvis køn spillede en vigtig rolle i valget af emner og interaktionspartnere, jf. dæknavne som MsgrQmwebcam og århuspigetjkr. Der er i materialet en tendens til at orientere sig i forhold til kulturelle stereotyper, som fx SannePigen, der *smiler glad og 
lykkeligt til alle* og senere rødmede *af alt den opmoeksomhed*. Hun fremstillede sig dermed som en favnende kvinde der besad en forventelig portion beskedenhed og dannelse. Ligesom mange af de andre lidt ældre chattere lagde SannePigen vægt på at være imødekommende og venlig over for alle og forventede det samme i retur:

Eks. 8

*Tænker om ICE_COOL har fortravlt til at hilse....*tsk-tsk*.

Hun var 'en pæn pige', så da nogle af de lidt frækkere kvinder, som fx Blaze og særligt Quims, rullede sig ud sammen med manden JIK i en længere associationsleg med klare seksuelle undertoner, bidrog hun kun reaktivt og 'artigt':

Eks. 9

SannePigen : Quims.......hvad hjerne er fuldt af.................. ${ }^{*} \mathrm{G}^{*}$ JIK : SP $<<$ Løber lemmet over med??

SannePigen : JIK.......Måske *GGG*

Mens seksualiteten ofte løb som en både humoristisk og flirtende sidediskurs i seniorernes chat, tyder meget på at den i de unges chat i højere grad havde et undersøgende og afprøvende element. I nedenstående eksempel legede Salem og Baddie gennem deres forholdsvis seriøse diskussion om kvaliteten og størrelsen på deres bh'er med den stereotype kønsopfattelse. Pigerne viste deres bevidsthed om brysterne og ikke mindst deres størrelse som kvindeligt symbol. De foregav at ønske en verden hvor kropslige attributter ikke havde altafgørende betydning en verden uden kropslig determination - samtidig med at de udnyttede den stereotype kønsopfattelse til at fremkalde respons fra de maskuline deltagere. Selv om det kan diskuteres hvor bevidste pigernes handlinger var, finder jeg et tydeligt islæt af leg og eksperiment med kvindekroppen som signal. Pigerne legede med kroppens forhold til kønnet og kønnets forhold til den stereotype kropslighed der følgelig destabiliseredes.

Eks. 10

Baddie: *HVOR4 R JEG IKKE EN DRENG!! Så slipper man da 4 de tåbelige BH'er!!!*

G@rfield: Baddie......du kan ski da bare gå uden

Salem: bADDIE...FORTAEL MIG OM DET DE FANDENS PATTER

ER DER Sq KUN FOR DRENGENES SKYLD!! 
Bidrag til en karakteristik af identitetskonstruktion på nettet ...

Baddie: Salem.... Bøjlerne stikker når de lige pludselig borer sig ind $i$ brystet på en!!*Ømmer sig!*

Salem: Baddie...jamen vi vil sq nødig gå uden*gg a

Baddie: Salem... *GG* Nix!*G*

Salem: Baddie..bvard hoenge babberdie..

Baddie: Salem.. Ja unen bh!*GG* Nej ikke mig!! Kunne nok godt gå

uden selvom jeg lige r gået et $n r$. op!

Smartoz: [] Baddie... Der er voksne til stede *S* []

Salem: Baddie...ma har prøblemer med at finde søde bhér fordi jeg

ikke kan FORDRAGE de satans kradse blonder*gg* B

Salem: Baddie....øvz hva ma bruger kun c men det er $s Q$ oxo fint

$n o k^{*} g g^{*}$

Baddie: Salem.. Min mor en en 95 f eller g.. kan ikke huske d....

Salem: Baddie...stakkels dig hvid du følger efter!!

G@rfield: ...bher fåes i 5 størrelser A B C D og nå dada

Baddie: Salem.. Så får jeg lavet en operation! D r helt 100!!

Salem: Baddie.....ma ville gerne have mindre!!

Baddie: Salem.. Jepper!!*SuX!*

Pigerne bekræftede hinanden i deres identitetsarbejde, men deres emnemæssige enighed til trods fremstod deres kønsidentitet ikke ens. Baddie erstattede ofte $\mathrm{s}$ med $\mathrm{z}$ og ks med $\mathrm{x}$ og spillede dermed på den stereotype forestilling om at piger er mere emotionelle og affekterede $\mathrm{i}$ deres omgangstone end drenge. Hun gav knus og kram til alle dem hun kendte i chatten, og beskrev sin krop inciterende om end med en - tror jeg - påtaget uskyldighed som Salem understøttede selv om hun i øvrigt forsøgte at iscenesætte sig selv langt mere maskulin og rå end Baddie ved at bande og kommentere mere nøgternt og karskt. De spejlede sig i hinanden og i drengenes kommentarer og fik på den måde forhandlet sig til en virtuel identitet - eller dele af den.

Identitetsfremskrivning er et fælles projekt der kræver forhandling og gensidighed. Nogle, som fx McBitter, kunne på relativ kort tid etablere en rimelig klar identitetskontur, mens andre identitetskonstruktioner var mere komplekse og krævende. På samme måde som face i den fysiske verden er interaktionelt forhandlet og til stadighed kræver en overensstemmende linje, fik de etablerede chattere også med tiden opbygget et face eller en chatidentitet som de øvrige deltagere havde en særlig forventning til. I nedenstående eksempel blev JIK's skrivefejl "kuld" for "klud" øjeblikkelig påtalt af tre andre deltagere, hvad der er en rimelig høj responsfrekvens i materialet ${ }^{5}$. Det at JIK's ytring fik så 
mange responser, hænger sandsynligvis sammen med at en central del af JIK's virtuelle face netop var sproglig korrekthed og overskud. Han skrev altid hurtigt, sjovt og fejlfrit og konsekvent i harmoni med chatstilen, dvs. med regibemærkninger, farve, emfatisk tegnsætning etc. Det at JIK korrigerede sig selv inden andre nåede det, er et eksempel på virtuel facework idet han med sin kommentar forsøgte at foregribe de andres forventelige kommentarer. Han nøjedes ikke med at lave en bagudrettet reparatur, men kommenterede samtidig på det facetruende $\mathrm{i}$ at lave skrivefejl. På én gang gjorde han lidt grin med sig selv (for hællevede da) og antydede at hans etos var så højt at han simpelthen ikke burde lave fejl og dermed måtte være lidt ved siden af sig selv (D'oh) hvad Memaid34 replicerede på ved at antage at skrivefejlen foranledigedes af tastaturet:

Eks. 11

JIK : *propper en kuld i gabet på rellutten*

JIK : klud! for hællevede da...D’oh!!!

Påskehanekylling : JIK*LOOOOOOOL*.......KULD??????????

rellut : *ka altså ik li kuld og det er oZ giftigt*

Mermaid34 : JIK....................har du stjålet mit..tastatur ???? *GGGGGGGGGGGG*6

Men en ting er face, en anden ting er identitet (jf. Femøe Nielsens kritik af Goffman (Nielsen 1993)), for selv om meget tyder på at JIK's face som fejlfri skribent var så vigtigt for ham at han ydede øjeblikkeligt facework for at beskytte det, er det ikke nødvendigvis ensbetydende med at det var den mest centrale del af hans identitet. Med sin facework-reparatur fik JIK nemlig ikke alene korrigeret sin egen trussel mod eget face, han fik også manifesteret sig som en chatter med høj etos og ydermere med tilstrækkeligt kognitivt overskud i situationen til at udforme reparaturen sjovt og uden selvhøjtidelighed. Han fik dermed udbygget sin chatidentitet samtidig med at han indikerede at situationen og dermed relationerne var så vigtige for ham at han ville gøre en særlig indsats. Hans chatidentitet var altså ikke kun den fejlfri og hurtige. Hans investering i situationen bidrog til hans selvfremstilling som en der ikke bare er ligeglad med sin fremtoning, og bekræftede de andre og ham selv i at chatten betød noget for ham samtidig med at han udviste et selvironisk overskud. 
Bidrag til en karakteristik af identitetskonstruktion på nettet ...

\subsection{Refleksiv positionering og gruppeidentitet}

Et markant træk ved chatten var forskellene på de etablerede chattere og de nye, "newbies" (Jensen 2009:90). Selv om chatten kan karakteriseres med Goffmans begreb "encounter", dvs." a natural unit of social organization in which focused interaction occurs" (Goffman 1961:7), med ét visuelt og kognitivt fokus, nemlig at skrive sammen i det pågældende chatrum, var interaktionen ikke kendetegnet ved at alle handlinger havde en fælles relevans for alle. Mange chattere, særligt de nye, forsøgte at etablere dyadiske relationer af privat karakter ${ }^{7}$, mens de mere etablerede ofte foretrak den offentlige fælles interaktion. Førstehåndsindtrykket af den offentlige chatinteraktion var at den var præget af en masse hilsner og interaktionsforsøg blandet med indlæg til forskellige samtidige interaktionsforløb hvor man som ny chatter kunne have svært ved at blive indlemmet og taget alvorligt som interaktionspartner. Gennem deltagerobservationer i forbindelse med ph.d.-projektet erfarede jeg at selvom chatfællesskabet umiddelbart virkede åbent og imødekommende, var den refleksive positionering en langvarig proces der i høj grad byggede på ærlig og vedvarende deltagelse, dvs. på høj deltagelsesfrekvens og en intention om at bidrage til fællesskabet. Dette aflæstes primært af interaktions- og chatstilen, men også af fx valg af samtaleemne.

De etablerede deltagere opfattede chatten som et fællesskab som opretholdtes af en fælles base (altid samme chatrum) og hyppigt onlinesamvær. Selv om det konkrete formål med at chatte kunne veksle fra ønsker om varige venskaber til behov for kortvarig adspredelse, opbyggedes der blandt de etablerede chattere bestemte forståelser af hinandens chatidentitet og af hvad den enkelte kunne forventes at bidrage med i chatten. Denne refleksive positionering (Davies og Harré 1990), dvs. den position den enkelte havde fået forhandlet sig frem til i det pågældende chatrum ved at positionere sig selv og lade sig positionere af andre, var altså i høj grad afhængig af det samspil der var mellem de etablerede chattere.

Ligesom Lomborg senere konstaterede at genreforventningerne på Facebook går i retning af det underholdende formuleret i en hverdagslig og spontan tone, gerne tilsat ironi (Lomborg 2013:111ff), var det også i høj kurs i chatten at være sjov og underholdende:

Eks. 12

MamaDevil : Typisk...når jeg kommer skrider de sjove.........* ${ }^{*} G G G G *$ 
Chatterne var i det hele taget meget sprogligt kreative og bekræftede hinanden løbende i det attraktive i denne interaktionsform ved en ekstra intensiv deltagelse i ord- og rollelegende interaktionsforløb (Hougaard 2004).

To andre positioneringer dominerede mit materiale. Jeg kaldte dem $\mathrm{i}$ afhandlingen entertainere og dørmænd, men denne skelnen er ikke interessant i denne sammenhæng. Kendetegnende for begge positioneringer var deres fokus på relationer idet de gerne samtidig kommunikerede med mange forskellige. Relationskommunikationen udmøntede sig dels i imødekommende hilsner, dels i faciliterede interaktionsforløb hvor bidrag fra alle i chatrummet var velkomne så længe det var underholdende. Fokus var på det socialiserende, anerkendende og sjove så at chatrummet forblev attraktivt og interessant. Nedenstående eksempel viser et sådant underholdende interaktionsforløb hvor flere chattere deltog $\mathrm{i}$ at bekræfte hinanden og deres fælles formål: at udfordre og lege med hinandens associationer:

Eks. 13

Ana : Scetter mig lige lidt hen i krogen og venter på en loegemand der kommer og ordner...GG

JIK : *hiver lige kitlen på og hOpPeR over til Ana*

Ana : Heiiiiii Laegedims.....ej hvor er det en flot .....øøøh kittel du har.....GG

JIK : Ana $<<*$ ser meget lægeagtig ud*..Hvor har vi ondt i dag??

SNUS : Ana: Prøv lige at se dén pandelampe, han render rundt med * $\mathrm{GGG}^{*}$

Ana : Ahhhhh Hr. Doktor....sådan bare javnt over det hele.....SSGG

JIK : Snus $<<$ Du sku' bare vide....hehehe...60 watt

JIK : Ana $<<*$ trykker rundt omkring på din Ana-tomi*...Her??

Ana : JIK...ej lidt mere til den ene side....og så lidt ned....GG

JIK : Ana $<<$ Her?...oO(Her føles det som om der er noget, der godt ku' være ømt..eller sart)

Ana : Meget sart Hr. Doktor.....blid massage tak.....GG

JIK : Ana $<<$ Hehehehehe...skal nok være meeeeget blid...*B*

Ana : JIK.....det gloeder mig.....GG

JIK : *griber blidt om patientens sarte....steder...nulrer mææægtig forsigtigt*

Med sin fornemmelse for frække antydninger og ordleg positionerede JIK sig med standup-lignende kaliber, men han var ikke alene om at 
skabe dette forum for rolle- og ordleg. Denne samværsform blev af de ældre chattere fremhævet som særligt animerende og konstituerende for gruppeidentiteten. Det at ovenstående og lignende rollelege ikke bare var en accepteret, men ofte også attraktiv samværsform, var i høj grad med til at skabe en særlig gruppeidentitet i dette chatrum.

Over tid og gennem indbyrdes opbygget kendskab og praksis skabtes et fællesskab og en gruppeidentitet der endte med at blive så stærk at da Tele Danmark i midten af 2001 ændrede Opasiachat.dk's chatsystem til et mere faciliteret system, dvs. med nemmere adgang til opsætning og forudprogrammerede handlinger, enedes mange af de etablerede chattere om i samlet flok at flytte tilholdssted, og de flyttede derfor over til en ny privatejet chat, reneord.dk, der i udgangspunktet lignede den velbesøgte og velfungerende "gamle" Opasiachat.dk som efterfølgende lukkede efter nogen tid med dårlige besøgstal.

Selv om materialet viste at der var stor udskiftning af deltagerne i chatten, mest i rummet "Andre Unge", oplevede mange et solidt tilhørsforhold til chatten og det virtuelle fællesskab og således også de forskellige interaktionsformer der prægede chatten, herunder bekræftelsen af og samarbejdet om udviklingen af hinandens virtuelle identitet. Særligt i "Andre Seniorer" var humoren og legen i højsædet, hvad der naturligvis havde betydning for at særligt de virtuost ordlegende og energiske sider af de enkelte chatteres virtuelle identitet var dominerende.

Chat kan karakteriseres som fatisk kommunikation fordi kontakten og fællesskabet var bærende elementer, men interaktionen handlede ikke kun om at komme i kontakt eller bekræfte hinanden som samtalepartnere. Selvfremstilling og identitetsforhandling fyldte som vist en del i materialet selvom der var en klar tendens til at det var den virtuelle identitet der fokuseredes på. Begrebet virtuel er valgt for at understrege det særegne ved interaktionen at den foregik mellem anonyme deltagere hvis specifikke, situationstilpassede identitet ikke nødvendigvis stemte overens med deres off-line identitet, men alligevel var virksom og betydningsfuld i den konkrete sammenhæng. Eksemplerne viser at selv om vi interagerer i en anonym kontekst med mennesker vi måske aldrig skal møde igen, er deres identitet, eller det at vi klart fornemmer at de ikke er chatrobotter, men ægte mennesker med personlighed og individuelle særpræg, vigtig og virksom for os. I chatsammenhæng var begrebet virtuel derfor centralt for at understrege vigtigheden af det virkelige, mens virkelighedsforpligtelse $i$ de sociale medier, fx Facebook, slet ikke er omgærdet af denne usikkerhed og derfor ikke rum- 
mer samme afgørende analytiske indsigter. Det gør derimod begrebet medialisering, hvad jeg vil vise i næste afsnit.

\section{Identitet på Facebook}

Efter at have gennemgået forskellige eksempler på forsøg på skabelse og forhandling af den virtuelle identitet $i$ chat vil jeg nu forsøge at tegne konturerne af hvordan lignende handlinger kunne undersøges på Facebook. Grundet materialets lidenhed vil jeg begrænse mig til nedenstående forsigtige bud.

\subsection{Statusopdateringer som personlig prasentation}

Facebook anvendes både til personlig præsentation og social netværksdannelse (Linaa 2010). Selv om Facebook oprindelig var tiltænkt en funktion som udvidet telefonbog og kontaktkanal til gamle venner, er den anden side, som mere handler om aktuel selvfremstilling eller identitetskonstruktion, meget fremherskende. På Facebook beskriver man logbogsagtigt egne bedrifter, overvejelser og holdninger og bruger dermed sin egen facebookside som en art dagbog eller scrapbog med beskrivelser af højdepunkter i sit liv i ord og billeder ${ }^{8}$. Selv om der også er en chatfunktion på Facebook, er det facebookvæggens interaktionsmuligheder der dominerer både den gængse forståelse og denne artikel. Pga. sin miniblogging-form kan facebookdeltagelse umiddelbart synes at være en solitær og introvert aktivitet, men via systemet lægges der op til indbyrdes kommentering og forholden sig. Nogle statusopdateringer efterspørger eller opfordrer endda eksplicit til interaktion og respons:

\section{Eks. 14}

Eleverne får dårligere eksamenskarakterer end årskarakterer og hvorfor? Jo det er da meget nærliggende at elevernes manglende netadgang spiller en væsentlig rolle - tag diskussionen her eller på \#sme_e tjek www.smee.dk for baggrund om it og gymnasieskolerne

Mange nøjes alligevel med at efterlade et "like" - et virtuelt "thumbs up" - for på den måde at udtrykke en form for anerkendelse eller deltagelse. Forhandlingen af identiteten har, som tidligere skrevet, trængte vilkår pga. de usikre succeskriterier (Tække 2010). Det at kommunikere via de sociale medier efterlader brugerne med en grundlæggende "social ambivalens" fordi de ikke kan stole på at andre læser deres indlæg og accepterer deres kommunikative adfærd (Tække 2013). Alligevel er det mit bud at mange af deltagerne trodser denne usikkerheden og 
Bidrag til en karakteristik af identitetskonstruktion på nettet ...

bruger den mere eller mindre vellykkede interaktion på Facebook som et forum for konstant bearbejdning og forhandling af deres identitet.

\subsection{Likekultur og lykkediskurs}

Mens jeg i min afhandling om chat fandt ud af at det at få respons understøttede deltagernes tilhørsforhold, gruppedynamik og dermed gruppeidentitet (Hougaard 2004), er gruppefølelsen næsten ikke eksisterende på Facebook ${ }^{9}$. Men det er ikke ensbetydende med at man som deltager er uafhængig af de andre deltager og ikke lader sig påvirke af dem. Politiken.dk bragte i foråret 2013 adskillige artikler med temaet facebook-misundelse hvor der tværtimod refereredes til flere undersøgelser der viste at mange facebookbrugere fokuserer på de andres vellykkede liv, idylliske feriefotos og enorme høst af fødselsdagshilsner og dermed føler en "større utilfredshed med deres eget liv efter et besøg på Facebook" (Thorsen 2013). Den umiddelbare årsag er at statusopdateringerne på Facebook bliver en virtuel målestok for det gode, interessante liv og ikke kun for hvor interessant man kan fremstille sit liv og sin identitet på Facebook. Selvom statusopdateringer også kan fungere som efterspørgsler/invitationer og anmeldelser (Hougaard 2013:5), rummer langt de fleste samtidig en form for implicit selvrapportering og selvpromovering da man i reglen ikke anmelder eller inviterer til noget interessant uden selv at være en del af det eller i det mindste have dannet sig en mening om det.

I modsætning til den synkrone interaktion i chat hvor fokus var på det virtuelle her og nu, fungerer Facebook langt mere som forum for beskrivelser af og afrapporteringer fra det liv der leves mellem statusopdateringerne og ofte fremstilles i en opsummeret og forskønnet version. Mens det $\mathrm{i}$ chatten handlede om væren og det at skrive sig til momentan eksistens og identitet $i$ chatrummet, handler det $i$ de sociale medier mere om formidling eller fremstilling af fragmenter af de handlinger og oplevelser der over tid kan stykkes sammen til et udtryk for vores identitet. Begge fremskrivninger af identiteten må nødvendigvis være fragmenterede og iscenesatte, men der er efter min mening en afgørende forskel $i$ det at chatidentiteten sandsynligvis kun var virksom inden for det afgrænsede fællesskab som chatrummet udgjorde, mens facebookidentiteten for mange betragtes som en supplerende identitet. Ganske vist har langt de fleste deltagere på Facebook mulighed for at mødes ansigt til ansigt med deres facebookvenner og dermed sandsynligvis få korrigeret den forskønnede version, men alligevel bliver facebookidentiteten i mange tilfælde stærk og indtryksfuld. Det kan hænge 
sammen med at meget facebookinteraktion handler om gensidig bekræftelse af hinandens selvfremstilling.

I stil med min konklusion vedrørende responsfremkaldelse i chat der viste at det gælder om at formulere sit indlæg så "engageret, ekspressivt og performativt som muligt" (Hougaard 2004:267), kan der også på Facebook ses en tendens til at noget er mere respons- eller likefremkaldende end andet. Selv om denne undersøgelse er langt mere kompliceret på Facebook fordi der ikke er tale om et fællesskab eller en gruppe, mener jeg dog at kunne iagttage en tendens til at det der får mest feedback på Facebook, er det der kan roses. På Facebook vil vi tilsyneladende langt hellere rose og anerkende end kritisere. Om det er et nyt flot profilbillede eller billeder af ens børn, en aktuel humoristisk kommentar eller en endelig overstået eksamen, er tilsyneladende ikke så afgørende så længe der er fokus på at dele sin glæde og succes. Visse store begivenheder som bryllup, fødsel, fødselsdag eller ønskejobbet er særligt velegnede til at fremkalde respons og få likes som i nedenstående eksempel:

Eks. 15

Har i dag fået ønskejobbet! Afdelingslæge pr. 1 sep. i (...)! Fedt!

Du og 79 andre synes godt om dette.

5 af 58 kommentarer

Tillykke!!! Super sejt!!!

Super tillykke og velfortjent

... Og så siger du slet ikke noget på job i dag, altså... Stort tillykke til

dig, søde Lotte... Vi kommer til at savne dig...

Stolt datter!!:)

Stort tillykke, du er bare for sej Lotte

Lotte er tydeligvis lykkelig over at have fået dette job, men det gør naturligvis ikke hendes glæde mindre at kommentarerne giver udtryk for at hun har fortjent det, og at hun vil blive savnet hvor hun arbejder for øjeblikket. På denne måde samarbejder Lotte med sine facebookvenner om at konstruere sin identitet som kompetent og vellidt læge. Taget $\mathrm{i}$ betragtning at hun har en facebookvennekreds på 280, er 80 likes oveni de mange kommentarer også ganske højt.

Selv om kritiske kommentarer også kan udløse en kommentarstorm, er lykkediskursen dominerende. Og selv om der i offentligheden til stadighed lyder beklagelser over indholdsløse statusopdateringer, 
Bidrag til en karakteristik af identitetskonstruktion på nettet ...

som fx : Så er der aftensmad :), viser min mini-undersøgelse af statusopdateringer på Facebook at størstedelen af opdateringerne er positive og optimistiske:

Eks. 16

jeg elsker mit liv $\odot \odot \odot$

Synes ikke godt om længere - Tilføj kommentar - Del

ه 25 ه

og selviscenesættende af det perfekte, spændende og kærlighedsfyldte liv med opdateringer som disse:

Eks. 17

- Strand hygge og Grill sener ;-)

- 3 am and I'm on my way to an early (too early) flight. Next stop

Warwick, Leeds and Westminster University.

- Dagens eksperiment. Egenfabrikation af sushi sammen med SJ og A.

$\mathrm{Nu}$ kommer det sjove sammen med et køligt glas hvidvin :-)

- Søskendekærlighed

- Har netop overstået min første fest nogensinde som off Road groupie med brændte dæk, ægte burnere, baglæns rullefald over sofaryg og meget meget sjove mennesker midt inde i en skov.

- Så har familien valgt en hund.

- Stolt far

Alle disse statusopdateringer var billedtekster og afspejler på den måde desuden en tendens i vores "glansbilledeoverenskomst"10 til at dokumentere vores skønne liv via billeder på Facebook. Vores facebookhandlinger giver et billede af hvem vi er, og hvad vi står for. Sammen med vores statusopdateringer og vores kommentarer er de billeder, videoer og links vi deler, med til at konstituere vores virtuelle identitet fordi det hele fungerer som et samlet udsagn om vores tilbøjeligheder, vores personlighed og vores særpræg. Hver enkelt deltagers akkumulerede handlinger aflæses af de andre som et udtryk for hvem man gerne vil give indtryk af at være, og i langt de fleste tilfælde er facebookvennerne, publikum, med til at bekræfte denne udlægning. Selv om jeg har eksempler på at der benægtes eller tages afstand, se nedenstående eksempel, er det overordnede billede at den mest udbredte respons er den anerkendende og positive bekræftelse. 


\section{Tina Thode Hougaard}

Eks. 18

Respekt for den nye Pave, som tør sige tingene ligeud. Det kunne den danske folkekirke lære noget af, og politikerne ligeså. Homoseksuelle ægteskaber og homoseksuelles ret til at adopterer, hører ingen steder hjemme i det danske samfund eller den danske folkekirke, og burde forbydes hurtigst muligt.

Afsenderen af denne statusopdatering fik udelukkende negativ respons fra sine facebookvenner (14 kommentarer og ingen likes), fx

Eks. 19

Er det for at provekere os alle. Men med de udtalelser du har haft på fb den sidste tid, ja så tror jeg desværre at du mener det. Jeg tror bare at jeg vil lade den stå der. Jeg ryster helt af hidsighed.

Det fik ham til dels at prise ytringsfriheden, dels at opfordre disse venner til at slette ham af vennelisten hvis de ikke brød sig om hans holdninger eller udtalelser. Hans endelige kommentar til tråden tyder dog på at han med sin statusopdatering har forsøgt at fremstille sig selv som modig og provokerende, men også at han er blevet påvirket af responsen:

Eks. 20

Tænk hvis vi alle gik rundt og var enige om al ting. Det ville der ikke være meget udfordring i.

\subsection{Medialiseret identitet}

Interaktionen på Facebook er ikke kun medieret; den er også medialiseret. Medialisering er et udtryk for at medierne og deres logikker og vilkår i stigende grad styrer samfundet og den enkelte fordi en stadig større andel af interaktionen medieres, dvs. udføres via medier (Hjarvard 2007:30) og dermed styres af mediernes muligheder og begrænsninger. Medierne påvirker individet ved at muliggøre, men også styre og forandre den måde vi interagerer med og relaterer os til hinanden på (Hjarvard 2009:160).

Zoomer vi ind på Facebook som medie, er det vilkår at vi interagerer med multiple publikummer, afgørende for hvordan den enkelte konstant og refleksivt må afveje og tilpasse sin identitet og identitetsfremstilling. Mens identitetsarbejdet i chat handlede mest om at gøre den enkeltes handlinger og positionering som virtuel identitet virksom 
Bidrag til en karakteristik af identitetskonstruktion på nettet ...

og reel for de andre deltagere, er spørgsmålet om den enkeltes virkelige eksistens og handlinger ikke længere i fokus på Facebook og de øvrige sociale medier. Anonymiteten som vilkår og attraktion er blevet afløst af en tilsyneladende transparent eksistens hvis konvergens med den enkeltes øvrige adfærd og selvopfattelse ikke er usikker og uidentificeret på samme måde som i chatinteraktionen. Den enkeltes netidentitet regnes nu for fuldstændig overensstemmende eller i hvert fald proportional med den øvrige fremtræden. Mens interaktionen i chat kunne foregå relativt uafhængig af hvilken status og adfærd der kunne forbindes med deltagerne i "real life", dvs. uden at deltagerne kendte hinandens "sande" identitet, er autenticiteten og forpligtelsen på en ægte fysisk identitet en grundlæggende præmis for interaktionen på de sociale medier. Selv om dette grundvilkår stadig udfordres af det faktum at der oprettes profiler for kæledyr og fiktive personer, og at mange kendisser, herunder nogle politikere, har ghostwritere til at varetage profilen og skrive indlæggene, er diskussionerne om nettet som parallelverden og identiteten som psedoidentitet helt forstummet.

Derfor er det efter min mening i dag mere givtigt at diskutere medialiseringens betydning for den enkeltes identitetsarbejde og om begrebet medialiseret identitet er en frugtbar beskrivelse af hvad der er på spil angående sprog, interaktion og identitet. I den sammenhæng er der mindst to forhold der gør sig gældende: Det at ens netidentitet i dag i vid udstrækning opfattes som en del af ens samlede identitet og dermed ikke kan bagatelliseres eller bortforklares som leg eller uskyldig eksperimenteren, og det at fremskrivningen af netidentiteten er underlagt en voldsom medialisering. Medialiseringen kommer dels til udtryk ved at de sociale medier lægger op til et kort format, fx med Twitters 140-tegns begrænsning, dels ved at identitetsbeskrivelsen skal tilpasses et multipelt publikum hvor "en persons identitet hele tiden modificeres eller tilpasses gennem dialog med de personer, man aktivt kommunikerer med på sitet" (Klastrup 2010), og endelig det at der med tiden skabes en vis norm for hvordan man konstant framer og reframer sin identitet på nettet.

De akkumulerede statusopdateringer fungerer som ens netidentitet, og der er en tendens til at vi skriver statusopdateringer der kan anerkendes og likes og desuden framer vores opdateringer som "umiddelbare og aktuelle, men også som endnu et afsnit i en serie, der er "to be continued"' (Hougaard 2013:254). Vi gør det for at vise at vi er i konstant forandring, men sandsynligvis også fordi de sociale mediers ny- 


\section{Tina Thode Hougaard}

hedsstrøm fordrer at vi alle kontinuerligt bidrager, så vores opdaterede og aktualiserede netidentitet konstant kan være $\mathrm{i}$ vores relationers bevidsthed - og i vores egen.

\section{Konklusion og diskussion}

Med dette dyk ned i forskellige eksempler på webchat og facebookopdateringer har jeg fået undersøgt forskellige eksempler på konstruktion af netidentiteter. I webchat var der en forkærlighed for at fremstille sig selv som underholdende, veloplagt og ikke mindst i tråd med chatstilen, og på Facebook aner jeg en tendens til at man konstruerer sig som opdateret og anerkendelsesværdig. Selv om der er rum for stort set alle former for kommentarer og billeder (undtagen nøgenhed og diskrimination) på vores facebookvæg, konstrueres vores liv som en lang række stjernestunder, og vores selvfremstilling vidner om lykke og overskud, eller hvis dette ikke kan postuleres, så i det mindste om vid og selvironi.

Hvorvidt manglende (eller utilstrækkelige og for få) kommentarer eller likes af den enkelte på Facebook forstås som en udebleven bekræftelse eller ligefrem kritik, og om det påvirker den enkeltes generelle identitetsopfattelse og -konstituering, står stadig tilbage at undersøge. Ligeledes kunne det være interessant yderligere at undersøge i hvor høj grad den medialiserede identitet og ikke mindst den bekræftelse af den, som kommentarerne og likesene udgør, spiller sammen med personens offline-identitet. Som Bechmann (2013) skriver, er Facebook "ikke et fiktivt fællesskab" uden betydning for det øvrige liv. Vores virtuelle eller digitale identitet eksisterer ikke kun $\mathrm{i}$ en parallelverden for de fă ${ }^{11}$, for Facebook fungerer i dag som en fuldt etableret og accepteret måde hvorpå vi bliver ajourført med hinandens liv.

Måske bidrager Facebook til at vi får et rigere og mere facetteret indtryk af hinandens samlede identitet ved at supplere med den del af vores identitet vi udfolder når vi færdes digitalt og via skrift og billeder, men det er også muligt at tolke begrebet medialiseret identitet som en beskrivelse af en situation hvor identiteten er til stadig forhandling pga. mediernes determinerende indvirkning og fordi vi hele tiden søger at tilpasse os skiftende situationer og relationer. En identitet i flux.

\section{Noter}

1 Der arbejdes i "Digital Footprints" under Aarhus Universitet på en dataindsamlingsløsning der giver bedre vilkår for at "tappe" al interaktion på 
Bidrag til en karakteristik af identitetskonstruktion på nettet ...

Facebook, men dette er endnu i sin vorden. Jeg har derfor kun indsamlet data i mindre portioner i det omfang min egen deltagelse på Facebook gav mig mulighed.

2 Blogger hvis "sande identitet" var omgærdet med en del mystik og faktisk så eftertragtet at der udlovedes en dusør for navnet. http://politiken.dk/ kultur/tvogradio/ECE1458498/dusoer-udloves-paa-nettet-for-bitterfissenbethanys-identitet/

3 Ifølge en samkøring af Facebooks registreringer og Dansk Statistik: http:// www.nettendenser.dk/2013/01/25/facebook-statistik-2013-for-danmarksadan-er-befolkningen-fordelt/ fra januar 2013 var der på dette tidspunkt 3.031.980 danskere på Facebook.

4 Alle skrivemåder i citater som i original.

5 Indlæg fik sjældent flere end to responser.

6 Mermaid34 havde forinden skrevet forkert i hvert eneste indlæg og havde derfor joket med at den slags er tastaturets skyld.

7 Enten åbenlyst i den fælles tilgængelige chat eller ved at oprette samtidige private chatrum.

8 Facebookbrugernes aktiviteter og deltagelsesfrekvens er meget divergerende. I denne artikel tager jeg udgangspunkt i de faktiske aktiviteter og de aktive facebookbrugere.

9 Man kan dog melde sig ind i gruppe og på den måde få noget der minder om interessefællesskaber; dog uden indbyrdes forpligtelse og dermed meningsgrænse.

10 Udtrykket er hørt i et foredrag af filosof Morten Albæk i 2010.

\section{Litteratur}

Baron, N. (1998). Letters by phone or speech by other means: the linguistics of e-mail, Language \& Communication, nr. 18:133-170.

Bays, H. (1998). Framing and face in Internet exchanges: A socio-cognitive approach, Linguistik Online, http://www.linguistik-online.de/bays.htm

Bechmann, A. (2013). Facebook er ikke et fiktivt fællesskab, Augustus nr. 1, http://www.au.dk/augustus/vis/artikel/facebook-er-ikke-et-fiktivt-faelles$\underline{\text { skab/ }}$

Bruckman, A. (1993). Gender swapping on the internet, Proc.INET'93 http:// lab4.psico.unimib.it/nettuno/forum3/free download/amy_s bruckman gender_swapping_on_the internet_512.pdf

Butler, J. (2005). Giving an Account of Oneself, Fordham University Press citeret efter A.S. Sørensen (2012). 
Cherny, L. (1999). Conversation and Community: Chat in a Virtual World, Stanford: CSLI Publications Lealand Stanford Junior University.

Danet, B. (1998). Text as Mask: Gender, Play, and Performance on the Internet, i: S. Jones (red.), Cybersociety 2.0. Revisting Computer-Mediated communication and Community. Thoursand Oaks, CA: Sage Publications.

Davies, B. \& R. Harré (1990). Positioning: The Discursive Production of Selves, Journal for the Theory of Social Behaviour, 20 (1):43-63.

Donath, J. \& d. boyd (2004). Public displays of connection, BT Technology Journal, 22 (4):71-82.

Gergen, K. J. \& M. Gergen (2005). Social konstruktion - Ind i samtalen, København: Dansk Psykologisk Forlag.

Goffman, E. (1961). Encounters. Two Studies in the Sociology of Interaction, Oxford: Bobbs-Merrill.

Goffman, E. (1955) On Face-Work: An analysis of ritual elements in social interaction, i: Psychiatry 18 (3):213-31.

Goffman, E. (1992(1959)). Vore rollespil i hverdagen, København: Hans Reizels Forlag.

Gurak, L. \& S. Antonijevic (2009). Digital Rhetoric and Public Discourse, i: A.A. Lunsford, K.H. Wilson, R.A. Eberly (red.), The SAGE Handbook of Rhetorical Studies, Thousand Oaks, CA: Sage Publications:497-507.

Herring, S.C. (1995). Gender and Democracy in computer-mediated communication, Nordlyd 23:1-20.

Hougaard, T.T. (2004). Ncermest en leg. En undersøgelse af sprog og interaktion $i$ dansk webchat, upubliceret ph.d.-afhandling.

Hougaard, T.T. (2013). Så fik jeg da lige skrevet en artikel om Facebook - om så og lige i statusopdateringer på Facebook, i: Widell, P., S. Borchmann, I. Schoonderbeek, O. Togeby og T.T. Hougaard (red.), Festskrift til Henrik Jørgensen, Aarhus Universitetsforlag.

Jensen, J.L. (2009). Fra onlinefællesskaber til onlinenetværk: Facebook som augmentering af den sociale virkelighed, MedieKultur, nr. 46:86-99.

Klastrup, L. (2010). Sociale fortællinger - statusopdateringers funktion på sociale netværkssites, EMU - Danmarks Undervisningsportal, http://design. emu.dk/artikler/1018-socialefortaellinger.html\#

Kolko, B.E. (1999). Representing Bodies in Virtual Space: The Rhetoric of Avatar Design, The Information Society, 15:177-186.

Lomborg, S. (2013). Genreforhandling som kommunikativ praksis på Facebook, i: J.L. Jensen \& J. Tække (red.), Facebook. Fra socialt netvoerk til metamedie. København: Samfundslitteratur:95-116.

Luhmann, N. (2000 (1984)). Sociale systemer, København: Hans Reitzels Forlag.

McRae, S. (1997). Flesh Made Word: Sex, Text and the Virtual Body, i: D. Porter (red.), Internet culture, London \& Oxford: Routledge.

Meyrowitz, J. (1986). No sense of Place, Oxford: Oxford University Press. 
Bidrag til en karakteristik af identitetskonstruktion på nettet ...

Miller, C.R. \& D. Shepherd (2004). Blogging as Social Action: A Genre Analysis of the Weblog, $\mathrm{i}$ : Into the Blogosphere: Rhetoric, Community, and Culture of Weblogs. University of Minesota. http://blog.lib.umn.edu/blogosphere/blogging as social action.html

Miller, V. (2008). New media, networking and phativ culture. Convergence, The international Journal of Research into New Medie Technologies, 14,4: 387-400 - citeret efter A.S. Sørensen (2012).

Nielsen, M.F. (1993). Det dualistiske face. Et forslag til en revision af Goffmans faceworkteori, i: M. Kunøe \& J. Cramer (red.), 4. Møde om Udforskningen af Dansk Sprog, Aarhus Universitet.

Stone, A.R. (1992). "Will the Real Body Please Stand Up?", i: M. Benedikt (red.), Cyberspace: First Steps, Princeston: MIT Press.

Stuedahl, D. (1998). Kropsløs og kønsløs? Om kønsidentitet på internettet, Kvinder Køn og Forskning, nr. 1:22-33.

Sørensen, A.S. (2010). Facebook i et hverdagslivsperspektiv, i: A.-M. Mai, \& A.S. Sørensen (red.), Interstitiel Litteratur, Kultur og Medier. Aktuel forskning ved Institut for Litteratur, Kultur og Medier.

Sørensen, A.S. (2012). Facebook - selvfremstilling, small talk og social regulering, MedieKultur, Vol. 28, Nr. 52:132-152.

Sørensen, B.H. (2001). Chat - leg, identitet, socialitet og loering, København: Gads Forlag.

Thorsen, N. (2013). Hver tredje bliver misundelig over andres Facebook-'likes', Politiken.dk, 8.3.

Togeby, O. (2015). Sprog og identitet, Skandinaviske Sprogstudier 3, Aarhus Universitet.

Turkle, S. (1994). Constructions and Reconstructions of Self in Virtual Reality, Mind, Culture, and Activity, vol. 1, 3, http://www.jacktoolin.net/pratt/ readings/Sherry Turkle Const-Reconst-Self.pdf

Turkle, S. (1995). Life on the screen. Identity in the Age of the Internet, Simon \& Schuster.

Tække, J. (2010). Social konstruktion af personlig identitet på Facebook, https://pure.au.dk/portal/files/22799401/SMID 2010 Jesper_T_kke.pdf

Tække, J. (2013). Facebook og social ambivalens, i: J.L. Jensen og J. Tække (red.), Facebook. Fra socialt netvoerk til metamedie, København: Samfundslitteratur:71-91.

Villesen, K. (2005). Vi blotter os på nettet, Information, 29.7, http://www. information.dk/109813

Warnick, B. (2007). Online Rhetoric: A Medium Theory Approach, New York: Peter Lang Publishing, Inc.

Watzlawick, M.P., J.H. Beavin \& D.D. Jackson (1968). Pragmatics of Human Communication. A Study of Interactional Patterns, Pathologies and Paradoxes, London: Faber and Faber. 